\title{
A ausência eloquente: ciência política brasileira, povos indígenas e o debate acadêmico canadense contemporâneo ${ }^{3}$
}

The eloquent absence: Brazilian political science, indigenous peoples, and the contemporary Canadian academic debate

\section{Introdução}

O Brasil é um dos países com maior diversidade sociodemográfica e linguística do mundo (BÉLLIER, 2013). Segundo o último censo o Instituto Brasileiro de Geografia e Estatística (IBGE), 896,917 mil indivíduos se autodeclararam indígenas no país, perfazendo 0,4 $\%$ da população nacional (BRASIL, 2010). Organizados em mais de 230 etnias, estes grupos se fazem presentes em todas as regiões do país e vêm, progressivamente, demonstrando maior capacidade organizacional para se fazerem representar politicamente. Nas eleições de 2018, os povos indígenas brasileiros conseguiram eleger sua segunda representante ao Parlamento federal em toda

\footnotetext{
1 Pós-doutorando do Departamento de Estudos Latino-Americanos da Universidade de Brasília (ELA/UnB), Brasilia, DF, Brasil.

2 Professor Adjunto do Programa de Pós-Graduação em Ciência Política da Universidade Federal do Pará, Belém, PA, Brasil. E-mail: <leobarros@ufpa.br>

3 Uma versão preliminar deste artigo foi apresentada no $3^{\circ}$ Congresso Internacional de Povos Indígenas da América Latina, realizado entre 3 e 5 de julho de 2019 na Universidade de Brasília. A presente versão se beneficiou dos comentários das professoras Soraia Sales Dornelles e Maria Regina Celestino de Almeida, além dos demais participantes, a quem eu expresso minha gratidão. Igualmente, agradeço aos pareceristas anônimos, cujos comentários certamente contribuíram para melhorá-lo. Eventuais erros e omissões, no entanto, remanescem de minha inteira responsabilidade.
} 
sua história, ${ }^{4}$ além de já contarem com um número significativo de candidaturas a cargos no Executivo e Legislativo municipais pelo menos desde 1976 (PAULA, 2017).

Ademais, a política de demarcação de territórios tradicionalmente ocupados por povos indígenas levada a cabo pela Fundação Nacional do Índio (Funai) já reconheceu 486 terras indígenas em todo o país, abrangendo o total de $13 \%$ do território nacional. ${ }^{5} \mathrm{Em}$ um país fundado sobre a iniquidade de acesso à terra, não deixa de surpreender a constatação de que, em conjunto com o México, o Brasil se destaca na América Latina como uma das nações em que o reconhecimento oficial de terras tradicionalmente ocupadas por povos indígenas mais avançou nas últimas décadas (RRI, 2015).

Por que alguns grupos indígenas conseguem suas demarcações territoriais e outros não? Por que alguns conseguem mais rapidamente do que outros? O que explica os dois grandes "picos demarcatórios" da década de 1990 ? $^{6}$ O que explica que o Serviço de Proteção aos Índios (SPI) tenha sido extinto em 1968 e uma instituição similar tenha sido concebida para substituí-la, e não outra com um desenho distinto ? $^{7}$ É possível o surgimento de partidos políticos indígenas com viabilidade eleitoral? O que a progressiva organização política dos povos indígenas pode significar em termos de desafios

4 O cacique Xavante Mário Juruna foi o primeiro indígena eleito deputado federal no Brasil em 1982 pelo Partido Democrático Trabalhista (PDT) do Rio de Janeiro, e se manteve como o único até a eleição para o Legislativo federal de 2018, quando Joênia Wapichana se elegeu pela Rede Sustentabilidade.

5 O processo demarcatório de terras indígenas no Brasil é regulado pelo Decreto n 1.775 , de 8 de janeiro de 1996, e compraz sete fases. Hoje, segundo dados do Instituto Socioambiental (ISA), 721 terras indígenas se encontram em diferentes estágios do processo, sendo 118 em identificação, 43 identificadas, 74 declaradas e 486 homologadas e reservadas. Dados disponíveis em: https:// terrasindigenas.org.br/. Acesso em: 16 jan. 2019.

6 Chamamos de "picos demarcatórios" os anos de 1991 e 1998, em que foi verificado o maior número de terras indígenas demarcadas no Brasil em termos absolutos e em termos de extensão no período pós-redemocratização. O monitoramento das demarcações territoriais indígenas é realizado em tempo real pelo ISA, que dispõe de uma plataforma interativa que permite a análise, em termos quantitativos e qualitativos, de cada uma das terras indígenas formalmente demarcadas no Brasil. Ver: https://terrasindigenas.org.br/. Acesso em: 30 set. 2018.

7 OServiço de Proteção aos Índios e Localização de Trabalhadores Nacionais - posteriormente renomeado apenas como Serviço de Proteção aos Índios, fundado em 1911, foi a agência brasileira responsável pela administração das populações indígenas do país até 1967, quando, após escândalos de corrupção e desvio de função, foi substituída pela Fundação Nacional do Índio (Funai), que perdura até nossos dias. Para uma ampla análise iconográfica e acadêmica daquela instituição, ver Freire (2011). 
à ordem política e econômica estabelecida no país ${ }^{8}$ Estas e tantas outras perguntas relativas aos povos indígenas brasileiros e às políticas públicas desenhadas para atendê-los poderiam dar ensejo a pesquisas no campo da ciência política brasileira. Todavia, nenhuma destas questões foi abordada a partir do uso de teorias, variáveis e metodologias características deste campo em nosso país.

Os campos do direito, em menor escala, e da antropologia, com larga vantagem, são duas disciplinas que já contam com um importante acúmulo de pesquisas, livros, teses e artigos se debruçando sobre inúmeros objetos de estudo relativos aos povos tradicionais brasileiros, especialmente os povos indígenas. ${ }^{9}$ De fato, obras como as de Eduardo Viveiros de Castro, Manuela Carneiro da Cunha, João Pacheco de Oliveira e Alcida Rita Ramos, para ficarmos em apenas alguns exemplos, gozam de amplo reconhecimento acadêmico dentro e fora do país, atestando sua qualidade empírica e teórica.

Lamentavelmente, o mesmo não se passa no campo da ciência política brasileira. Há um imenso hiato, um "silêncio ensurdecedor" do campo sobre as questões indígenas. Com honrosas exceções, ${ }^{10}$ em resumo, pode-se afirmar, com certo grau de certeza, que os principais scholars e grupos de pesquisa em ciência política do Brasil não se interessam em estudar assuntos relacionados à questão indígena.

8 Essas duas últimas perguntas foram feitas e respondidas, no âmbito de estudos da América Latina, respectivamente por Van Cott (2006) e Yashar (2005).

9 Os povos tradicionais brasileiros incluem, além dos povos indígenas, os quilombolas, os geraizeiros, raizeiros, quebradores de coco babaçu, vasanteiros, faxinalenses, ciganos, seringueiros, pescadores artesanais, entre outros (ALMEIDA, 2006). Neste artigo trataremos especificamente dos povos indígenas brasileiros. Resta claro, no entanto, que a denúncia da quase total ausência de estudos sobre este grupo populacional realizada neste artigo se estende para todos esses demais povos tradicionais. Poder-se-ia dizer, sem sombra de dúvidas, que a ciência política brasileira ignora, em larga medida, a existência de grupos demograficamente minoritários, o que o cientista político Wesley Matheus (comunicação pessoal) chama de "genocídio estatístico", referindo-se à prática comum de analistas políticos de tratarem os baixos números demográficos destas populações como irrelevantes para a realização de investigações quantitativas no campo da ciência política.

10 Trataremos com mais vagar sobre esta lacuna na sequência deste artigo. 
Durante nossa pesquisa de doutorado, ${ }^{11}$ investigando comparativamente a participação de povos indígenas em processos de revisão das políticas de reconhecimento territorial no Brasil e no Canadá, tivemos que recorrer quase que exclusivamente às teorias e hipóteses desenvolvidas pelos cientistas políticos deste país. Em que pese ainda a predominância de estudos antropológicos e do campo do direito também no contexto canadense, similar ao caso brasileiro, já há uma considerável produção acadêmica sobre objetos tão amplos tais como a política de negociação territorial, seus efeitos para o aumento do bem-estar das populações aborígenes e as relações entre governos municipais e comunidades indígenas autogovernadas, entre outros tópicos. Em resumo, há um incipiente, porém em franco desenvolvimento, campo de pesquisa que se debruça sobre povos indígenas, políticas indigenistas e temas afins a partir da mirada disciplinar da ciência política. ${ }^{12}$

O objetivo deste artigo, portanto, é o de apresentar ao contexto acadêmico brasileiro, tanto para alunos de graduação como pesquisadores já amadurecidos, os recentes desenvolvimentos da literatura canadense abordando diversos aspectos da relação entre o estado canadense e os povos aborígenes, almejando iniciar um debate entre nós sobre a pertinência desta agenda de pesquisa para o contexto brasileiro. Sem a pretensão de ser exaustivo, nesta revisão de literatura, o trabalho terá foco sobretudo nos objetos de pesquisa relativos à questão territorial, apresentando, de forma abrangente, os objetos de pesquisa, as teorias utilizadas, as metodologias empregadas e suas conclusões.

11 Tese intitulada (Un)changing Indigenous land claims policy: evidence from a crossnational comparison between Brazil and Canada, defendida em janeiro de 2019 no Programa de Pós-Graduação em Ciência Política da Universidade Federal de Minas Gerais.

12 Foge ao escopo deste artigo discutir as razões pelas quais o Canadá desponta como um contexto acadêmico particularmente promissor no campo de estudos das questões indígenas a partir da mirada da ciência política. Ademais, desconheço qualquer reflexão sistematizada nesse sentido. Poderíamos especular amplamente que, uma vez que a questão indígena é largamente reconhecida como "a" questão social daquele país, nada mais esperado que a ciência política também se debruce sobre ela. Alternativamente, colegas canadenses aventam a possibilidade de que eles preenchem a lacuna deixada pelos antropólogos, cuja relação política com os povos nativos não seria das melhores. Estas são, no entanto, apenas sugestões que devem ser submetidas a pesquisas rigorosas alhures. 
O texto está organizado da seguinte maneira: primeiro, demonstraremos empiricamente a seguinte afirmação: ao lançarmos um olhar para a produção acadêmica dos últimos vinte anos, veremos que a ciência política brasileira não se interessou sobre questões indígenas. Em segundo lugar, faremos uma breve apresentação ao leitor brasileiro do panorama das populações aborígenes do Canadá, de modo a situá-lo no debate posterior; na sequência, trataremos sobre três temas específicos na a literatura: negociações territoriais entre o estado canadense e esse segmento populacional; escolha de determinado desenho de política de reconhecimento territorial; e o que se denomina de "federalismo aborígene"; finalmente, apresentamos visões críticas de scholars indígenas e não indígenas sobre as políticas indigenistas do estado canadense. Concluímos com um chamado aos pesquisadores brasileiros para empreenderem pesquisas mais aprofundadas sobre as populações indígenas brasileiras.

\section{A ausência eloquente: quantificando o desinteresse da ciência política brasileira sobre questões indígenas}

É preciso, de saída, sustentar empiricamente uma afirmação tão grave, qual seja, a de que a ciência política brasileira não se interessou por estudar os povos indígenas brasileiros em toda sua pluralidade e a política do Estado brasileiro a eles endereçada. Para tanto, decidimos realizar uma pesquisa bibliométrica, investigando a frequência da temática indígena em dois conjuntos de dados, dentro de um recorte temporal de vinte anos (1997-2017): em primeiro lugar, pesquisamos no banco de dados do Catálogo de Teses e Dissertações da Coordenação de Aperfeiçoamento de Pessoal do Ensino Superior (Capes), ${ }^{13}$ a partir da palavra-chave

13 A Plataforma Sucupira é o meio pelo qual o Sistema Nacional de Pós-Graduação faz a coleta de informações sobre os programas de pós-graduação de todo o país com fins de avaliação e publicidade de sua produção acadêmica. Trata-se do sistema que alimenta o Catálogo de Teses e Dissertações da Capes. O site consultado foi: http://catalogodeteses.capes.gov.br/catalogo-teses/\#!/. Acesso em: 27 jun. 2018. 
"indígena", ${ }^{14}$ filtrado pela área de concentração "ciência política"; em segundo lugar, abordamos os sete principais periódicos do campo da ciência política brasileira, ${ }^{15}$ analisando os resumos de todos os artigos publicados no período, buscando por trabalhos que preenchessem apenas duas condições: i) abordassem algum aspecto da vida dos povos indígenas brasileiros; e ii) utilizassem teorias e métodos pertinentes ao campo da ciência política.

A pesquisa sobre a presença da temática indígena em nível de pós-graduação stricto sensu no campo da ciência política é importante porque dá a medida da vitalidade do tema, ou seja, se esta se configura como objeto de interesse dos mestres e doutores do país. No período analisado, constatamos a existência de $47(\mathrm{~N}=47)$ trabalhos, 32 em nível de mestrado e 15 em nível de doutorado. $\mathrm{O}$ Gráfico 1 a seguir apresenta estes dados.

14 Optamos por esta palavra-chave pelo fato de que ela também captura referências no plural "indígenas" - e pelo fato de que esta é, sem dúvida, a forma mais disseminada de tratamento dos povos indígenas brasileiros, também expresso nos títulos dos trabalhos pesquisados. Não há retorno, no Catálogo de Teses e Dissertações da Capes, para o termo "silvícola" e tampouco para "aborígene". Este fato contrasta com o caso canadense. O termo "aborígene" significa, constitucionalmente, o reconhecimento de três povos originários: Métis, Inuit e primeiras nações (first nations). Por outro lado, os termos "indígena","autóctone"e "primeiras nações"são amplamente usados de forma intercambiável, com preferência para este último. É plausível supor que algum trabalho tenha utilizado em seu título ou resumo apenas o nome de uma determinada etnia e não o termo genérico "indígena", o que não seria captado por nossa pesquisa. No entanto, isso demandaria uma pesquisa mecânica por mais de trezentos nomes de etnias distintas, algo fora do escopo deste artigo. Assim, embora não possamos afirmar com certeza de que abrangemos o universo de pesquisas do campo da ciência política sobre povos indígenas, podemos afirmar que nossa amostra é, sem sombra de dúvida, representativa.

15 Os periódicos analisados, seguidos de sua classificação no sistema Qualis da Capes, foram os seguintes: Revista Brasileira de Ciências Sociais on-line (A2); Dados - Revista de Ciências Sociais (A1); Revista Brasileira de Ciência Política (B1); Opinião Pública (A1); Brazilian Political Science Review (A2); Lua Nova: Revista de Cultura e Política (A2); e Novos Estudos Cebrap (A2). 
Gráfico 1 - Número de trabalhos de pós-graduação sobre a questão indígena na grande área da ciência política - Brasil (1997-2017)

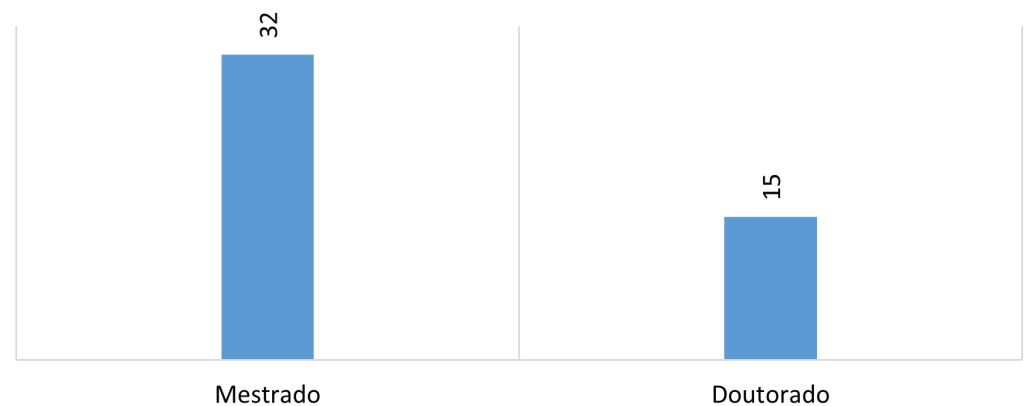

Fonte: Catálogo de Teses e Dissertações da Capes.

Elaboração própria.

Constata-se, dessa forma, que a maioria dos trabalhos de pós-graduação na grande área da ciência política no período analisado é em nível de mestrado, ou seja, são trabalhos mais pontuais e, usualmente, com menor escopo teórico e empírico que as teses de doutorado. Estas apresentam um número exíguo - apenas 15 teses relacionadas à temática indígena na ciência política foram apresentadas no Brasil no período analisado. ${ }^{16}$ Em outras palavras, considerada em comparação com temas "nobres" da ciência política, tais como instituições políticas, partidos e sistemas eleitorais, para

16 Com a exceção de uma dissertação de mestrado defendida em 1997, todos os demais trabalhos se deram a partir de 2003. Entre 2007 e 2017 foram defendidos 3.779 trabalhos para obtenção de títulos (2.804 dissertações e 975 teses) na área de ciência política e relações internacionais. N=47 representa $0,012 \%$ da produção do campo. Para mais detalhes, ver: https://www.gov.br/capes/ pt-br/centrais-de-conteudo/20122017-cienciapolitica-relatoriodeavaliacao-quadrienal2017-final-pdf/ view. Acesso em: 18 abr. 2020. 
ficarmos em apenas alguns exemplos, o tema pode ser considerado praticamente desconhecido. ${ }^{17}$

Curiosamente, quando olhado com minúcia, a partir dos programas de pós-graduação, o tema ainda se concentra mais naqueles de ciência política tout court $(\mathrm{N}=33)$ do que nos programas interdisciplinares, tais como os programas de pós-graduação em integração política da América Latina ${ }^{18}(\mathrm{~N}=4)$, cartografia social e política da Amazônia ${ }^{19}(\mathrm{~N}=2)$ e diplomacia ${ }^{20}(\mathrm{~N}=2)$. Em segundo lugar, mas ainda muito atrás dos programas de pós-graduação em ciência política, vêm os programas de relações internacionais ${ }^{21}$ $(\mathrm{N}=6)$. Conclui-se que, se o tema é praticamente desconhecido da grande área da ciência política no Brasil, o é ainda mais nos programas de RI ou de caráter interdisciplinar. O Gráfico 2 abaixo demonstra, de forma inequívoca, estes dados.

17 Os diversos capítulos que conformam o livro publicado pela Associação Brasileira de Ciência Política com um balanço do campo entre 1960 e 2015 apresentam um variegado quadro que dá respaldo a essa afirmação. Num deles, aprendemos que, entre 1988 e 2014, 279 artigos com temática neoinstitucionalista foram publicados nos principais periódicos do campo, abordando relações entre poderes, presidencialismo, federalismo, eleições e sistemas partidários e regimes políticos. Ademais, entre 1991 e 2014, 278 artigos de teoria política normativa foram publicados. Por fim, mas não menos importante, entre 1994 e 2014, ainda a partir de uma amostra de periódicos, foram publicados 41 artigos relacionados aos temas de mulheres e participação/representação político eleitoral (AVRITZER; MILANI; BRAGA, 2016).

18 Sediado na Universidade de São Paulo.

19 Com sede na Universidade Estadual do Maranhão.

20 Ambas desenvolvidas no Instituto Rio Branco.

21 Localizamos defesas de tese (4) e mestrado (2) nas instituições Universidade de Brasília e Universidade Federal do Rio Grande do Sul. 
Gráfico 2 - Número de trabalhos sobre questões indígenas nos programas de pósgraduação da grande área da ciência política - Brasil (1997-2017)

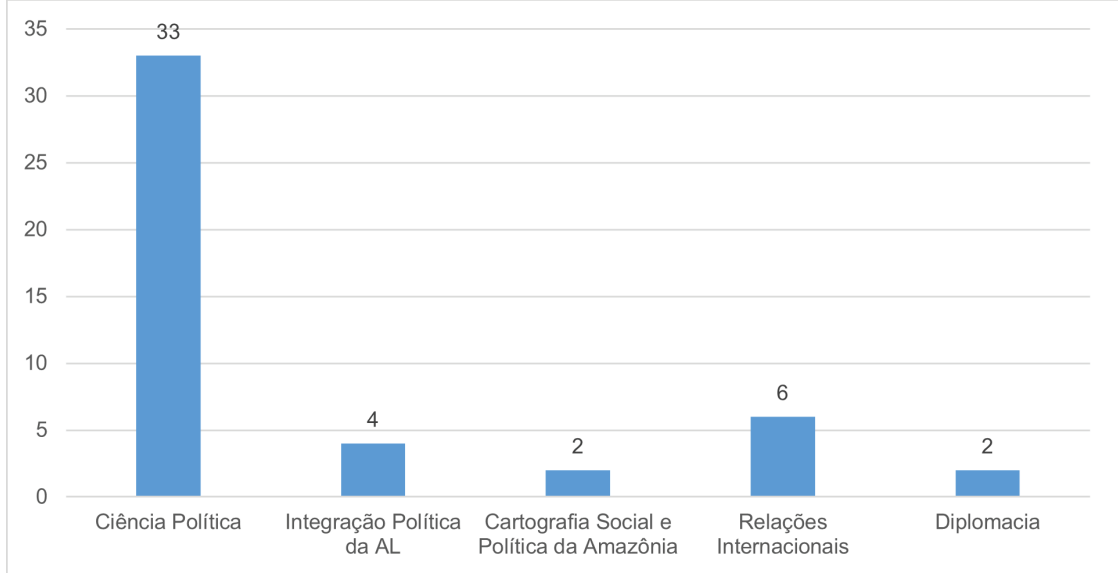

Fonte: Catálogo de Teses e Dissertações da CAPES.

Elaboração própria.

O baixo número de trabalhos em nível de pós-graduação sobre povos indígenas no campo da ciência política brasileira se reflete de forma dramática na produção de artigos publicados nos periódicos de grande circulação da disciplina. Uma análise de sete importantes periódicos de grande circulação da área de ciências sociais aplicadas revela o imenso vazio de interesse sobre a temática indígena. ${ }^{22}$ A partir da análise do resumo de 2.621 artigos, apenas dois deles cumpriram os pré-requisitos por nós estabelecidos para que fossem considerados artigos do campo da ciência política sobre a temática indígena no Brasil, quais sejam, os trabalhos de Adriano Codato e

22 Utilizamos como base o conceito de referência para o quadriênio 2013-2016, conforme disponível na Plataforma Sucupira. Todos os periódicos elencados pertencem ao extrato superior do Qualis da Capes. Nosso recorte é arbitrário, pois a investigação de todos os periódicos do campo da ciência política demandaria um esforço metodológico hercúleo. Em outras palavras, esse recurso buscou dar maneabilidade aos dados apresentados. Estamos cientes do possível viés de seleção implicado em tal procedimento e o deixamos aqui explicitado. Convidamos colegas cientistas políticos a expandirem a pesquisa aqui apresentada, de modo a torná-la mais abrangente. Disponível em: https://sucupira.capes.gov.br/sucupira/public/consultas/coleta/veiculoPublicacaoQualis/ listaConsultaGeralPeriodicos.jsf. Acesso em: 18 abr. 2020. 
colaboradores (CODATO; LOBATO; CASTRO, 2017) e Fernandes (2015). ${ }^{23}$ A Tabela 1 sumariza estes dados.

Tabela 1 - Frequência de artigos com temática indígena em periódicos de ciência política - Brasil (1996-2017)

\begin{tabular}{cccccc}
\hline Periódico & Período & Volumes & Edições & $\begin{array}{c}\text { No de artigos } \\
\text { analisados }\end{array}$ & $\begin{array}{c}\text { No de artigos sobre } \\
\text { questão indígena }\end{array}$ \\
\hline $\begin{array}{c}\text { Revista Brasileira de } \\
\text { Ciências Sociais }\end{array}$ & $1997-2017$ & $12-33$ & 63 & 609 & 1 \\
\hline Dados & $1996-2017$ & $39-60$ & 78 & 560 & 1 \\
\hline $\begin{array}{c}\text { Revista Brasileira de } \\
\text { Ciência Política }\end{array}$ & $2011-2017$ & - & 18 & 173 & 0 \\
\hline Opinião Pública & $2000-2017$ & $6-23$ & 38 & 300 & 0 \\
\hline $\begin{array}{c}\text { Brazilian Political } \\
\text { Science Review }\end{array}$ & $2007-2017$ & $1-11$ & 25 & 128 & 0 \\
\hline $\begin{array}{c}\text { Lua Nova: Revista de } \\
\text { Cultura e Política }\end{array}$ & $1997-2017$ & - & 61 & 499 & 2 \\
\hline Novos Estudos Cebrap & $2005-2017$ & - & 36 & 352 & 2.621 \\
\hline Total & & & & & 0 \\
\hline
\end{tabular}

Fonte: sites dos periódicos da plataforma Scielo.

Elaboração própria.

Nota: * Excluindo resenhas, entrevistas e demais textos no do campo da ciência política

Esses números parecem se coadunar com os achados de Leite (2017). Em artigo recente, reconstruindo o campo da ciência política brasileira por meio de extensa pesquisa sobre periódicos, áreas temáticas e abordagens teórico-metodológicas, este autor demonstra que esse campo de estudos se estrutura aos moldes estadunidenses, ou seja, privilegia pesquisa empírica em detrimento de trabalhos de cunho teórico e, ademais, apresenta intensa concentração de publicações em objetos "nobres" de estudo, tais

23 O primeiro se debruça sobre a participação eleitoral indígena no pleito de 2014, ao passo em que o segundo traz para o contexto brasileiro a discussão levada a cabo nos Estados Unidos da América e no Canadá sobre a homossexualidade indígena. 
como, entre outros, comportamento político, instituições políticas, sistemas eleitorais e relação Executivo-Legislativo. Entre as 29 áreas temáticas codificadas por Leite, não há menção a alguma que pudesse aglutinar, de forma específica, trabalhos sobre populações tradicionais brasileiras.

Por fim, qual o espaço do tema indígena nos encontros específicos da área? Uma investigação na programação dos encontros bienais da Associação Brasileira de Ciência Política (ABCP) e do Fórum Brasileiro de Pós-Graduação em Ciência Política (FBPGCP) também pode revelar o grau de (des)interesse dos politólogos brasileiros sobre a temática dos povos indígenas. $\mathrm{O}$ acesso ao site da associação, que cobre da $8^{\mathrm{a}}$ à $11^{\mathrm{a}}$ edição do encontro, ${ }^{24}$ permite observar se mesas redondas, seminários temáticos ou sessões especiais foram dedicados ao tema. Aqui também, no entanto, o resultado é desanimador: entre as 75 mesas redondas, 293 sessões das áreas temáticas da associação e 64 sessões especiais realizadas entre 2012 e 2018, nenhuma dessas atividades se apresentava com o fim explícito de discutir os temas de estudo relacionados aos povos indígenas. De igual modo, nas quatro últimas edições do Fórum, ${ }^{25}$ nenhum dos dez grupos de trabalho se dedicou a investigar o tema.

Em suma, com baixo número de trabalhos em nível de pós-graduação, ausência completa de atividades em nível de encontros nacionais da ABCP e do FBPGCP dedicadas aos povos indígenas brasileiros nos últimos oito anos e uma virtual inexistência de artigos sobre o tema nos periódicos relevantes para a área da ciência política, pode-se afirmar, com grande confiança, de que não houve, nas últimas duas décadas, interesse da ciência política

24 O site da ABCP contém abas relativas aos encontros da associação apenas a partir de sua 8a edição. Foram elas: $8^{\circ}$ Encontro (de $1{ }^{\circ}$ a 4/8/2012, em Porto Alegre); $9^{\circ}$ Encontro (de 4 a 7/8/2014, em Brasília); $10^{\circ}$ Encontro (30/8 a 2/9/2016, em Belo Horizonte); $11^{\circ}$ Encontro (de 31/7 a 3/8/2018, em Curitiba). Programações disponíveis em: https://cienciapolitica.org.br/index.php/. Acesso em: 9 jul. 2018.

25 A primeira edição deste fórum, com perfil mais modesto que os encontros da ABCP e mais focados nos trabalhos em andamento dos pós-graduandos, foi realizada em Belo Horizonte, em 2009. Infelizmente, não há site disponível do evento para consulta. As demais edições desse encontro foram as seguintes: em São Carlos (de 20 a 22/7/2011); Curitiba (de 31/7 a 2/8/13); em Niterói (de 4 a 6/8/2015); em Teresina (de 4 a 7/7/2017). Sites dos eventos disponíveis em: http://www. forumcienciapolitica.com.br/edicoesanteriores/ Acesso em: 9 jul. 2018. 
sobre a temática indígena no Brasil. Está além do escopo deste artigo discutir as causas explicativas deste fenômeno. Seu resultado prático, no entanto, é claro: a ciência política brasileira não dispõe de objetos de estudo no campo da política indigenista e dos povos indígenas brasileiros e, consequentemente, não dispõe de hipóteses de trabalho e tampouco achados teóricos ou empíricos frutos de pesquisas de fôlego. Em outras palavras, o cientista político interessado em trabalhar com a questão indígena brasileira a partir das teorias e métodos próprios de seu campo disciplinar deve buscar exemplos em outros contextos de pesquisa. Nós fomos buscá-los no Canadá, país sobre o qual nos debruçamos comparativamente durante nossa pesquisa de doutorado, e nossos achados são discutidos na sequência deste artigo. Antes, porém, proveremos ao leitor brasileiro um breve panorama da questão indígena naquele país.

\section{Povos indígenas e política indigenista no Canadá: um breve panorama histórico}

O Canadá é um país de vasta extensão territorial e uma população de 33 milhões de habitantes, entre os quais 1.172 .790 se autodeclaram indígenas (CANADA, 2011). Entre os brasileiros, o país é conhecido por sua alta qualidade de vida, estando, efetivamente, entre os países com os maiores índices de desenvolvimento humano, liberdade econômica e nível educacional. Também é relativamente conhecido por seu multiculturalismo estruturado, sobretudo, na coexistência - tensa, diga-se de passagem - entre o chamado Canadá anglófono e a província do Québec, francófona (GAGNON; IACOVINO, 2007).

Menos conhecido, no entanto, é seu complexo panorama pluriétnico relativo aos povos aborígenes dentro das fronteiras do estado canadense. De início, é preciso indicar para o leitor brasileiro que o Constitution Act de 1982 reconhece como povos aborígenes ou autóctones do país três grupos distintos: i) os povos indígenas, ou como vêm sendo chamado nas últimas décadas, Primeiras Nações (First Nations ou Premiére Nations); ii) os Inuit, conhecidos anteriormente pelo termo pejorativo "esquimós", comprazendo os 
habitantes originários de praticamente a totalidade da região ártica; e iii) os chamados "mestiços" (Métis, em francês), compostos por um grupo de ancestralidade mista oriunda da relação entre os dois primeiros grupos e os colonizadores franceses ou ingleses. Estes grupos somam, juntos, 4,9 \% da população do país (CANADA, 2009).

Devido a constrangimentos de espaço, não abordaremos, neste artigo, a crescente literatura sobre os Inuit e os Métis. Nosso foco se concentrará, portanto, na relação da ciência política canadense contemporânea com as 617 comunidades indígenas espalhadas pelas dez províncias e três territórios da federação canadense.

A essa divisão tripartite, acrescente-se que a primeira categoria, a dos povos indígenas ou First Nations, pode ser dividida em dois grupos: os que são oficialmente reconhecidos pelo governo canadense como indígenas, indivíduos com status indígena (status indians) e os que se autodenominam indígenas, mas indispõem do reconhecimento oficial estatal, ou seja, indivíduos sem status indígena (non-status indians). Para complicar ainda mais, os grupos indígenas que se enquadram na primeira categoria podem ser um dos quais tenham assinado algum tipo de acordo com a coroa britânica, sendo denominados "povos indígenas com tratado" (treaty indians) ou, alternativamente, "povos indígenas sem tratado" (non-treaty indians) (CANADA, 2010).

A política indigenista canadense é secular, tendo, na formalização de tratados entre os povos colonizadores e os povos indígenas, seu pilar constitutivo. A proclamação real de 1763, por exemplo, afirma que os povos indígenas só poderão fazer transações de terra com representantes da Coroa britânica, estipulando a necessidade de uma negociação pública e feita de boa-fé entre as partes. Desde o início, portanto, as relações entre povos originários e colonizadores baseou-se numa relação entre nações (nation-to-nation), um 
padrão que se mantém em suas premissas básicas até os dias de hoje (ASCH, 2014). ${ }^{26}$

De "aliados" 27 da empresa colonizadora nos primeiros decênios da ocupação do território canadense, os povos indígenas passaram a ser progressivamente tratados, a partir do século XIX, como "dependentes do Estado" (wards of state), sobretudo a partir da edição do Indian Act em 1876, uma legislação de caráter abrangente que governa a vida dos povos indígenas canadenses até hoje. ${ }^{28} \mathrm{Com}$ uma população em declínio devido a epidemias e à miséria decorrente da reduzida capacidade de manter atividades econômicas e de subsistência tradicionais, os povos indígenas canadenses chegaram a uma situação calamitosa. O governo canadense, por seu turno, tomou medidas concretas para a total assimilação destes grupos à

26 Não faz parte do escopo deste artigo discutir todas as nuances do complexo debate sobre a conferência do estatuto de nação a povos indígenas, cujo grau de reconhecimento varia fortemente de um país a outro. À guisa de exemplo, poderíamos citar o caso dos Estados Unidos da América, que desenvolveu, historicamente, a compreensão de povos indígenas como "nações domesticamente dependentes", ao passo que, no Canadá, a denominação dos povos indígenas como "primeiras nações" é recente e ainda contenciosa no debate político daquele país. No Brasil, por sua vez, argumenta Ramos (1993), o debate foi interditado durante a ditatura e não parece ser parte importante do discurso político da Articulação dos Povos Indígenas do Brasil (Apib), atual organização de articulação nacional do movimento indígena brasileiro.

27 Em outras palavras, ressaltamos que os povos indígenas canadenses desenvolveram complexas alianças econômicas, políticas e militares com os impérios franceses e ingleses durante os primeiros séculos da colonização (LECLAIR, 2013; POELTZER; COATES, 2015). Quando chamamos a atenção para esse aspecto, não olvidamos, entretanto, o fato de que a correlação de forças entre colonizadores e colonizados pendia, ao fim do dia, para os primeiros em detrimento dos segundos.

28 A referida legislação sofreu algumas modificações ao longo do século XX, mas continua a ser a grande referência jurídica para as decisões das cortes e para orientar a ação governamental, similar ao Estatuto do Índio no Brasil. Para uma abordagem comparativa do caso brasileiro e canadense nesse aspecto, ver Silva (2016). 
sociedade dominante, levando a cabo uma série de políticas com este objetivo. $^{29}$

Os povos indígenas canadenses experimentaram um forte ressurgimento na cena pública canadense a partir do período após a segunda guerra mundial, em que membros dos povos indígenas lutaram valorosamente nos exércitos estadunidenses e canadenses e demandaram tratamento equânime nestas sociedades quando de seu retorno dos campos de batalha. Ademais, o crescimento da luta por direitos civis nos EUA também levou a uma maior organização e mobilização de povos indígenas em seu vizinho do Norte. Assim, quando o então Primeiro-Ministro liberal Pierre Eliott Trudeau propôs acabar com a legislação específica para os povos indígenas canadenses por meio de um White Paper em 1969, não foi uma surpresa que a reação contra esta proposta tenha sido tão vigorosa ao ponto de forçar um pedido de desculpas públicas por parte do governo canadense (SCHOLTZ, 2006; MISIARZ, 2017).

Nesse momento histórico, organizações indígenas já estavam se mobilizando comunitariamente e foram capazes de se tornar uma “ameaça crível”, em nível nacional, para o estado canadense e forçaram o estabelecimento, alguns poucos anos depois, de uma política de reconhecimento territorial indígena, a chamada "Política de Acordos Territoriais Compreensivos" (Comprehensive Land

29 Notoriamente infame foi a política dos pensionatos escolares (residential schoo/s). Entre 1831 e 1996, quando a última dessas "escolas" foi fechada, aproximadamente 130 instituições desse tipo foram fundadas. Estas consistiam, basicamente, em locais de provimento de educação formal compulsória para povos indígenas geridas por organismos religiosos, com o objetivo de "matar o índio dentro do índio" através da escolarização. Pais indígenas que não enviassem seus filhos para uma destas instituições estavam sujeitos à prisão. Nelas, crianças eram uniformizadas, proibidas de falar sua língua materna e de realizar quaisquer de seus ritos. Superlotadas e com equipe com pouco ou nenhum treinamento educacional, estas escolas se tornaram cenário de abusos sexuais, castigos físicos e outras formas de abuso físico e psicológico, levando a grande taxa de mortalidade entre seus alunos. Durante seu tempo de vigência, nada menos que cinco gerações de povos indígenas, Métis e Inuit passaram por uma destas escolas. A extensão do dano humano, social, cultural e psicológico causado aos povos tradicionais canadenses por parte dessa política é gigantesca e forçou o estado canadense a um pedido oficial de desculpas em 2008, seguido do estabelecimento de uma Comissão da Verdade e da Reconciliação com vistas ao estabelecimento de um realinhamento conciliatório entre os povos indígenas canadenses e a sociedade circundante (FRIEDERES, 2016). 
Claims Agreements Policy). ${ }^{30}$ Esta consiste, fundamentalmente, num processo de negociação entre povos indígenas e Estado canadense que visa à obtenção de um tratado que estabeleça, de forma definitiva, os deveres e direitos da partes envolvidas no que tange à delimitação do território reconhecido, o grau de autonomia política conferido, além de outros aspectos relativos à habitação, saúde, educação, geração de emprego e renda, atividades extrativistas, entre muitas outras. Entre 1975 e 2012, 24 acordos desse tipo ${ }^{31}$ foram fechados entre povos indígenas e o estado canadense, atingindo cerca de $40 \%$ do território do país (ANAYA, 2014).

A mobilização política dos povos indígenas canadenses teve novo ciclo de protestos a partir de 2013, com o nascimento do chamado movimento Idle No More (Apatia Nunca Mais, em tradução livre). A reação a uma proposta de mudança legislativa sobre a proteção aos cursos d'água desencadeou um processo de mobilização política de amplas proporções em todo o país e no exterior, revitalizando demandas dos povos indígenas por melhores condições de vida, respeito a seu modo tradicional de vida e por autonomia política e administrativa no quadro de uma luta pelo direito à autodeterminação (CÉLÉRIER, 2014; COATES, 2015; PALMATER, 2015; SOARES, 2018).

30 A história da celebração de tratados entre povos indígenas potências coloniais é fundamental para a compreensão da própria existência do estado canadense e sua abordagem aprofundada está descartada neste artigo. Para prover um quadro sintético ao leitor interessado, no entanto, destacaria: i) a celebração dos chamados tratados históricos numerados, que se desenrolaram entre 1850 e 1920 e comprazem a maior parte do atual território do estado canadense e; ii) o estabelecimento de um processo provincial específico na Columbia Britânica pelo então governador geral James Douglas, que deu origem aos chamados "Douglas Treaties", e que responde pela complexidade do panorama de reconhecimento territorial indígena naquela província. Uma abordagem histórica mais aprofundada desta questão pode ser encontrada em Coates (1992), Asch (2014) e Canadá (2010).

31 Vale lembrar ainda que há outra modalidade de negociação de tratados territoriais chamada de Acordos de Demandas Territoriais Específicas (Specific Land Claims Agreements), que, como o nome sugere, se dedica a negociar aspectos específicos das demandas territoriais que não foram incluídos originalmente nos tratados já negociados ou, alternativamente, renegociam cláusulas de tratados históricos que devem passar por uma atualização. Este é o caso, por exemplo, das etnias que celebraram tratados históricos com o estado canadense em que havia a previsão, por exemplo, de um pagamento anual de alguns dólares para cada membro do grupo. O que, à época do tratado pareceu um bom negócio em termos financeiros, já não faz mais sentido e precisa ser atualizado para valores monetários atuais. 
Como se pode depreender, essa história, aqui extremamente resumida, da relação entre o Estado canadense e os povos indígenas que nele habitam, é complexa e prenhe de acontecimentos e ações políticas que despertaram o interesse de alguns cientistas políticos no país. Na sequência deste artigo, apresentaremos três grandes campos de pesquisa que se abriram no panorama acadêmico daquele país na última década, quais sejam: o dedicado ao processo de negociação territorial entre o Estado canadense e povos indígenas; o dedicado à discussão comparativa sobre o desenho das políticas de reconhecimento territorial; e o debate sobre federalismo aborígene. É importante ressaltar que essa escolha é, em certo sentido, arbitrária e está relacionada a nossos próprios interesses de pesquisa, sem denotar nenhuma pretensão totalizante. Nesse sentido, encorajamos os leitores a descobrirem outros temas, mais afins a seus próprios objetos de interesse.

\section{O campo da indigenous politics: o debate acadêmico canadense}

O debate acadêmico da ciência política canadense sobre povos indígenas é amplo e diversificado (POELTZER; COATES, 2015). Daniel Salée (2006) e Martin Papillon (2008), para ficarmos em apenas alguns poucos exemplos, realizaram extensas pesquisas sobre a qualidade de vida dos povos indígenas, com especial interesse sobre o impacto dos tratados sobre indicadores de habitação, assistência social e educação, entre outros. Ken Coates (2015), por sua vez, investigou quantitativamente e qualitativamente os atos de protesto do movimento Idle No More, ao passo que Belanger e Lackenbauer (2014) e Ramos (2008) investigaram um amplo conjunto de protestos em todo o país, num recorte temporal de cinco décadas. Em suma, todo e qualquer trabalho que pretenda abordar o campo dos estudos sobre povos indígenas a partir do olhar disciplinar da ciência política naquele país defrontar-se-á com uma pluralidade de trabalhos, o que forçosamente o impelirá para um recorte arbitrário. 
Escolhemos três temas em meio a essa diversidade de objetos de estudo não apenas por estes estarem mais próximos de nossos interesses de pesquisa, mas também por entendemos que essa literatura se relaciona com problemas empíricos importantes nas esferas públicas do Brasil e do Canadá. Novamente, o intuito aqui é o de apresentar os principais autores, teorias e conceitos em cada um dos tópicos, sem pretensão de realizar estados da arte num espaço tão exíguo como o da seção de um artigo.

\section{Tema 1: fatores explicativos da política de reconhecimento territorial indígena}

O primeiro tema que gostaríamos de destacar, por sua relevância tanto no debate político brasileiro quanto no canadense, vai direto ao coração da questão indígena em todo o mundo: a efetividade das políticas de reconhecimento territorial. Aqui como lá, povos indígenas, agentes estatais, atores econômicos e militantes da sociedade civil têm interesse em saber sobre os elementos que podem lançar luz sobre os processos de reconhecimento de terras tradicionalmente ocupadas por povos indígenas. Além disso, a investigação do tema é relevante para o contexto brasileiro porque, entre outros motivos: i) o conhecimento sobre o processo demarcatório produzido pela antropologia não é capaz de fornecer explicações para um número moderado ou grande de casos; e ii) é possível que, no caso brasileiro, fatores relacionados a arranjos partidários e à composição de forças econômicas no interior do Congresso possam ter algum rebatimento sobre a política de reconhecimento territorial (SOARES, 2019).

Quais os fatores capazes de explicar seu funcionamento e, mais ainda, podem acelerar o reconhecimento estatal, uma vez que a demora para sua materialização pode significar a manutenção prolongada de uma grave situação de injustiça? Estas são as questões norteadoras do trabalho pioneiro do cientista político Cristopher Alcantara, professor da Western University, em seu 
livro, derivado de sua tese de doutorado, intitulado Negotiating the deal: comprehensive land claims agreements in Canada (2013). ${ }^{32}$

Esse autor parte da ideia - uma premissa do institucionalismo da escolha racional - de que grupos aborígenes e Estado canadense, quando entram em negociação com vistas à obtenção de um acordo territorial, agem buscando maximizar suas preferências. Assim, tais atores podem ou não ter convergência de objetivos, o que pode facilitar ou dificultar a obtenção de um resultado satisfatório para ambas as partes envolvidas. Ademais, não apenas a consideração das preferências entra em jogo na análise de Alcantara, mas também os incentivos (constrangimentos e oportunidades) que aborígenes e negociadores federais têm para barganhar. Por fim, esses incentivos são gerados pelas estruturas institucionais relevantes que, embora não determinem o resultado da interação entre os jogadores, circunscrevem o conjunto de resultados possíveis e a probabilidade de cada resultado ocorrer dada a interação desses elementos. Nota-se, portanto, que o autor se posiciona conceitualmente no campo analítico das interações estratégicas entre atores políticos, nesse caso, povos indígenas e governo canadense.

É importante ressaltar que Alcantara não trabalha com uma ideia abstrata de negociação entre atores com relação política simétrica, mas, antes, está ciente de que os povos aborígenes são a parte mais fraca dessa relação e que, portanto, estes devem convencer - por meios argumentativos ou de ação direta - os negociadores federais de que sua reivindicação é justa. Em outras palavras, os povos indígenas devem mostrar habilidades de negociação somadas a estratégias políticas que os coloquem em uma posição mais favorável para fazer avançar suas demandas.

Munido desse esquema analítico, Alcantara então seleciona os casos a serem estudados. Deliberadamente, o autor busca a maior variabilidade possível em sua variável dependente, a saber, a obtenção de um acordo territorial compreensivo. Assim, ele opta pelo estudo do acordo já completado pela Kwanlin Dün First

32 Esta seção se baseia na resenha que fizemos da referida obra (SOARES, 2017a). 
Nation e aquele ainda incompleto por parte das Kaska Nations da Liard Nation e Ross River Dena Council, ambos localizados no território Yukon, no noroeste do país. Além destes, analisa também a negociação já encerrada dos Inuit da porção nordeste da província de Labrador e Terra Nova, e aquela ainda não finalizada dos Innu da região sudeste e central daquela província. Procedendo dessa forma, Alcantara analisa dois conjuntos de casos de sucesso e insucesso que variam com relação aos povos envolvidos nas negociações, aos times de negociadores federais e a região.

Após realizar extensa pesquisa de campo, coletando documentos e entrevistando agentes públicos e lideranças indígenas envolvidas nas negociações, o cientista político apresenta seus achados. De acordo com sua análise, os elementos que favorecem a obtenção de um acordo territorial compreensivo são: $i$ ) a compatibilidade de objetivos entre governo e grupos indígenas; ii) o uso mínimo de táticas confrontacionais por parte desses grupos; iii) forte coesão grupal dos povos nativos no que se refere ao apoio ao processo de negociação; e iv) percepções positivas da capacidade dos grupos aborígenes por parte dos agentes governamentais. É a interação virtuosa entre esses elementos que aumenta a probabilidade de povos aborígenes e governo canadense chegarem a um acordo ou, alternativamente, em sua ausência, levarem as negociações a um fracasso.

Não apenas a obtenção de um acordo é almejada, mas também sua materialização de forma célere. Nesse sentido, Alcantara propõe os seguintes elementos como variáveis que afetam o compasso das negociações: i) o desenvolvimento de relações de confiança entre lideranças aborígenes e negociadores federais; ii) a presença de negociadores contratados fora do quadro da burocracia governamental canadense; e iii) a competição pelo uso das terras demandadas, sobretudo através da pressão pela realização de obras com vistas ao desenvolvimento econômico. Assim, não apenas ficamos sabendo dos elementos que podem auxiliar as partes envolvidas no processo de negociação a chegarem a um bom termo, mas também daqueles outros fatores que aceleram sua conclusão, poupando tempo, dinheiro e desgaste dos envolvidos. 
Não está no escopo deste artigo desenvolver, em profundidade, cada um destes achados de Cristopher Alcantara, o que já fizemos em outro trabalho (SOARES, 2017a). Apenas chamamos a atenção para o fato de que seu desenho de pesquisa, seu uso parcimonioso e pertinente da teoria e seu caráter fortemente empírico transformam-no num verdadeiro exemplo de uma investigação realizada completamente dentro das balizas teórico-metodológicas do campo da ciência política com repercussão direta sobre um debate importante da administração pública canadense. Não por acaso, o livro recebeu diversos prêmios desde sua publicação ${ }^{33}$ e é por nós, aqui, destacado como uma obra que pode servir de inspiração para cientistas políticos brasileiros interessados na temática.

\section{Tema 2: escolha do desenho da política de reconhecimento territorial indígena}

O segundo tema de interesse destacado por nós no debate acadêmico da ciência política canadense diz respeito ao debate sobre a escolha do desenho da política de reconhecimento territorial para os povos indígenas daquele país. Este assunto tem interesse para o público brasileiro por, pelo menos, três motivos: i) a ausência de um trabalho conclusivo sobre a escolha da manutenção, durante a década de 1960, de um modelo de política indigenista que seguia, em linhas gerais, aquelas já empregadas pelo SPI em detrimento de modelos alternativos; ii) pela quase completa ausência de trabalhos - mesmo na antropologia, diga-se de passagem - que comparam a política indigenista brasileira com a de diversos países; e, não menos importante, iii) as reiteradas tentativas de mudança do desenho da política de reconhecimento territorial em curso no país nos últimos

33 Entre os quais se destacam o Canadian Studies Network-Réseau d'Études Canadiennes Prize (2014), o International Council for Canadian Studies Pierre Savard Award (2014) e o Seymour Martin Lipset Best Book Award, da American Political Science Association (2017). 
anos e contemporaneamente. ${ }^{34}$ Vale a pena, portanto, investigar a literatura da ciência política canadense contemporânea em busca de insights que nos ajudem a pensar nosso próprio contexto nacional.

Por que o estado canadense escolheu a atual política de reconhecimento territorial - "politicamente arriscada", pois se baseia na negociação direta com os povos indígenas - quando dispunha de outros modelos, com menos envolvimento estatal, para adotar? A obra de referência nesse tópico é o livro da cientista política Christa Scholtz, professora da McGill University, intitulado Negotiating claims: the emergence of Indigenous land claim negotiation policies in Australia, Canada, New Zealand, and the United States (2006). A partir de um estudo comparativo internacional de quatro países, a autora propõe uma explicação para as escolhas dos agentes políticos destes estados por um determinado desenho de política de reconhecimento territorial indígena.

Scholtz parte da premissa de que o fato de diferentes países terem desenvolvido políticas para lidar com as demandas territoriais de seus povos indígenas significa que as sociedades não indígenas demonstram algum tipo de disposição para reconhecer este segmento populacional como parte integrante dos debates nacionais sobre o próprio conceito de cidadania. Não obstante, fatores domésticos interagem de forma significativa para produzir o desenho da política adotada em cada nação, desde os baseados em negociações diretas entre povos indígenas e governos federais (os casos do Canadá e da Nova Zelândia), aos que adotaram uma política de negociação lenta, gradual e limitada a apenas uma região do país (como na Austrália), até, por fim, os que não dispõem de nenhuma forma institucional de processamento dessas demandas, deixando-as a cargo das decisões judiciais (caso dos Estados Unidos).

34 Referimo-nos aqui, simultaneamente, às propostas de modificação do rito demarcatório realizadas pelos povos indígenas brasileiros na 1a Conferência Nacional de Política Indigenista, realizada em 2016, e, sobretudo, às propostas de alteração da legislação vigente via Congresso Nacional, impulsionadas pela Bancada Ruralista, as quais encontram sua expressão máxima no Projeto de Emenda Constitucional 215, que visa transferir a competência demarcatória de terras indígenas da Funai para o Legislativo federal. 
A autora vai em busca de um modelo analítico que permita explicar o maior número de casos possíveis, para além dos elementos específicos de cada contexto investigado. Para tanto, escolhe países com tradição colonial britânica, o que confere a estes uma constante que os une de forma intuitiva. Ao mesmo tempo, esses países divergem de forma significativa em termos institucionais, o que promove uma maior variabilidade de sua variável dependente, qual seja, a emergência de políticas de negociação territorial indígena. Engajando-se com a literatura sobre mudanças institucionais e política comparada, a autora desenvolve um argumento que se descola das tradicionais avaliações normativas das políticas de reconhecimento territorial indígena e busca a concretude dos dados empíricos.

Scholtz se insurge contra o que denomina de "tese do choque judicial", segundo a qual os poderes executivos dos países que adotaram políticas de negociação só o fizeram após serem provocados por decisões judiciais importantes, como os casos das decisões Calder, no Canadá, em 1973, e o Court of Appeal's Lands Case, na Nova Zelândia, em 1987. A premissa aqui é a de que os executivos nacionais seriam especialmente sensíveis ao ativismo judicial. Seu argumento, no entanto, propõe um exame mais detalhado dos processos políticos envolvendo as decisões pela escolha de uma determinada forma de política pública em face de seus policy competitors.

A partir dos dados coletados em sua extensa pesquisa de campo, na qual entrevistou 60 lideranças indígenas, agentes públicos e ativistas, além de realizar consultas a arquivos públicos dos gabinetes dos chefes de estados dos países analisados, Scholtz propõe que uma explicação mais plausível e completa para a adoção de uma política de negociação territorial indígena deve levar em conta não apenas o papel das cortes supremas, mas a interação destas com o poder de mobilização política dos povos indígenas. Para ela, a capacidade dos povos tradicionais de mostrarem como "ameaças críveis" ao capital político dos governos estabelecidos é anterior às decisões judiciais e com elas interage para pressionar, de forma decisiva, a adoção de uma política de negociação territorial 
"face a face". Sua ênfase na variável capacidade de ação coletiva dos povos aborígenes é central para que possamos resgatar o papel do protagonismo desses grupos na tomada de decisões que os afetam diretamente. Assim procedendo, Scholtz presta um grande serviço às análises políticas que, sem a consideração da agência política de grupos historicamente subalternizados, podem se fechar em variáveis institucionais descoladas de seu contexto politicamente contencioso.

\section{Tema 3: federalismo aborígene multinível}

Por fim, mas não menos importante, destacamos o prolífico e instigante campo do que se chama de federalismo aborígene, que tenta discutir o estatuto dos territórios indígenas no âmbito da federação canadense. Qual é a especificidade de um território indígena em países com sistema federalista, tais como o Canadá e o Brasil? Povos indígenas almejam autonomia política, mas o quanto os estados nacionais estão dispostos a ceder em termos de responsabilidade administrativa e econômica? No Brasil, ademais, há uma forte atuação da bancada ruralista no sentido da aprovação do Projeto de Emenda Constitucional 215/2000, cujo objetivo é transferir para o Congresso Nacional a competência demarcatória de terras indígenas, sob o argumento de que este processo tem um grande impacto sobre a dinâmica dos estados e que, portanto, são estes que devem debater e decidir sobre sua efetivação (SOARES, 2017b). Em suma, há um conflito aberto entre os estados da Federação brasileira e os povos indígenas, contenda que pode ser abordada, pelo cientista político interessado, a partir do prisma das teorias sobre o federalismo.

Destacamos, nesse sentido, a obra do cientista político e professor da Université de Montréal Martin Papillon, o qual vem se dedicando a pensar sobre o tema no contexto canadense. Muito embora não seja o autor de um livro específico sobre esse campo de investigação, a produção acadêmica de Papillon, desde sua tese de doutorado, tem aportado importantes reflexões sobre o assunto, além de uma série de outras pesquisas sobre a política indigenista e os povos indígenas 
daquele país (ver, inter alia, PAPILLON, 2008; PAPILLON, 2015; PAPILLON; BEAULIEU; GERVAIS, 2013; PAPILLON; LORD, 2013; PAPILLON; SENECÁL, 2011).

$\mathrm{O}$ fulcro da questão federalista no que tange aos povos indígenas, segundo o autor, é saber se territórios por eles tradicionalmente ocupados podem ser considerados uma terceira esfera de governo, distinta das esferas provincial e federal. Para responder a esta pergunta, Papillon parte da premissa de que as instituições do federalismo canadense não gozam de legitimidade perante os povos indígenas, uma vez que nenhum representante indígena foi convocado para participar das conferências de Charlottetown e do Quebéc em 1864, que lançaram as bases da confederação canadense. Essa exclusão "originária” da participação dos povos indígenas na fundação do moderno estado canadense limita sua atuação política até nossos dias, uma vez que ainda é expressiva a sub-representação de indígenas nas instituições intraprovinciais e interprovinciais (PAPILLON, 2012).

A questão de fundo desse debate é a crítica levantada por lideranças indígenas aos limites da soberania do estado canadense sobre suas aspirações de autodeterminação política, vistas com desconfiança por muitos agentes públicos por desafiar um dos pilares do estado-nação moderno, qual seja, a noção de soberania política irrestrita sobre um determinado território. Nesse sentido, o estado canadense reluta em ceder capacidade de autogoverno a uma população considerada até a constituição de 1982 como objetos de tutela governamental (PAPILLON, 2014).

Para complicar ainda mais o quadro, a relação individualizada do estado canadense com povos indígenas - que os classifica, como vimos, em distintos grupos aptos ou não a serem contemplados com as previsões legais do Indian Act - e os interesses econômicos provinciais fazem emergir um verdadeiro "mosaico" de situações em que as comunidades indígenas apresentam maior ou menor grau de capacidade administrativa e política de gerirem seus próprios territórios (PAPILLON, 2012). Como demonstraram empiricamente Alcantara e Nelles (2016) em estudo sobre o estabelecimento de parcerias entre 
governos locais e povos indígenas, o quadro é variado e ainda não permite uma apreciação de conjunto que forneça teorias de médio alcance e a proposição de hipóteses mais robustas.

Em suma, em que pese sua inconclusividade, os estudos de Papillon e outros autores sobre a interrelação entre os diversos níveis de governo do estado canadense e o variado panorama dos governos locais indígenas tocam no cerne da definição de soberania territorial do estado moderno e trazem à tona as inovações institucionais que têm surgido na vida cotidiana das centenas de comunidades indígenas em todo o país. Dessa forma, estamos diante de um tema de investigação que tem importantes repercussões não apenas nos estudos de administração pública e modelos de governança, mas também em discussões caras à filosofia política clássica.

\section{Olhares críticos}

Nesta seção final do artigo, abordamos brevemente as principais perspectivas críticas sobre o campo da indigenous politics presentes no cenário intelectual canadense. Isto é importante porquê demonstra que, à medida que se organiza um determinado campo de estudos no interior de uma disciplina, não apenas as narrativas dominantes sobre determinados objetos de estudo ganham proscênio como, simultaneamente, surgem perspectivas alternativas que estimulam o debate. Mais uma vez, o recorte aqui realizado é arbitrário e apenas indica aqueles autores que, em nosso julgamento, apresentam trabalhos mais completos e amplos sobre o campo da política indigenista no Canadá, não tendo a pretensão de esgotar a literatura em discussão.

Por um lado, há uma forte crítica teórica no campo oriundo de intelectuais indígenas já estabelecidos e influentes na cena acadêmica canadense. Entre todos os muitos pesquisadores membros de um grupo indígena, destaca-se, pelo escopo e profundidade de seu trabalho, o cientista político Gerald Taiaiake Alfred, professor de Indigenous Governance na Victoria University. De origem Mohawk, Alfred vem se destacando como um teórico importante no campo 
da teoria política normativa que serve de base aos reclamos dos povos indígenas canadenses por autodeterminação.

Esse autor busca resgatar as especificidades das diversas cosmogonias indígenas da América do Norte para que estas sejam o lastro normativo sobre o qual as demandas por autodeterminação devem se fundar. Em três de suas principais obras - Heeding the voices of our ancestors: Kahnawake Mohawk politics and the rise of native nationalism (1995), Wasáse: Indigenous pathways of action and freedom (2005) e Peace, power and righteousness: an Indigenous manifesto (2009) -, Alfred tece duras críticas não apenas ao Estado canadense, mas às lideranças indígenas que, a seu ver, deixaram as tradições ancestrais totalmente de lado para abraçar, sem reservas, não apenas o padrão de vida ocidental lato sensu, mas também suas formas jurídicas e organizativas. Ele argumenta que o mimetismo acrítico das formas de governo dos colonizadores despotencializa a agência política dos povos indígenas e, em última análise, colabora para a dissolução das identidades comunitárias no seio da sociedade circundante. Não por acaso, Poelzer e Coates (2015) localizam Alfred ao lado de Joyce Green, Kiera Ladner, John Borrows e Patricia Monture-Angus no campo dos "tradicionalistas", pensadores indígenas que enfatizam a singularidade cultural e política dos povos tradicionais e a colocam no centro de sua reflexão sobre as possibilidades de autonomia política numa perspectiva decolonial.

Outro dos intelectuais indígenas de destaque na ciência política canadense é Glen Coulthard, membro da Yellowknives Dene First Nation, professor no First Nations and Indigenous Program e do Departamento de Ciência Política da University of British Columbia. Em sua aclamada obra Red skins, white masks: rejecting the colonial politics of recognition (2014), ganhadora de vários prêmios no Canadá, ${ }^{35} \mathrm{o}$ autor parte do referencial do pensador francês Frantz Fanon para rejeitar, de forma veemente, a política de reconhecimento do Estado canadense como apenas mais um

35 A obra foi galardoada com o Frantz Fanon Outstanding Book da Caribbean Philosophical Association (2016); o The Canadian Political Science Association's C.B. Macpherson Prize (2014/2015); e o The Rik Davidson Studies in Political Economy Award (2016). 
instrumento de colonialismo com vistas à dominação e à assimilação dos povos indígenas canadenses.

O livro tem como objetivo principal desafiar a noção de que a atual política de reconhecimento territorial indígena canadense pode ser um componente de emancipação política dos povos originários. Coulthard é ácido ao identificar que os termos do debate territorial são postos pelo estado nacional, que opera para "domesticar" a radicalidade das demandas dos povos indígenas por autodeterminação. Utilizando o exemplo de seu próprio povo, o autor provê uma poderosa crítica ao sistema capitalista e colonialista de "dispossessão estruturada" das terras indígenas, concluindo seu livro com um chamado à ressurgência das lutas políticas a partir de uma perspectiva decolonial.

Cumpre destacar também as críticas à política indigenista canadense realizadas por autores não indígenas. Por sua amplitude, influência e repercussão midiática, o trabalho do cientista político Tom Flanagan certamente merece destaque especial, uma vez que sua obra aparece frequentemente como referencial incontornável no debate da ciência política canadense, ora para concordar com suas premissas ou, mais frequentemente, para fazer contraponto a elas. Professor de ciência política aposentado da Calgary University, Flanagan é um expert na história e demandas territoriais dos Métis e é um comentarista político conservador com relativa influência sobre o Partido Conservador canadense.

Sua obra First nations? Second thoughts (2000) causou polêmica e desencadeou um amplo debate público sobre suas proposições consideradas, por muitos, racistas. O centro de seu argumento é o fato de haver, em nível nacional canadense e internacionalmente, com pequenas variações, um conjunto de proposições sobre a relação dos povos indígenas e os estados nacionais que foram construídas e paulatinamente adotadas como inquestionáveis por uma coalização de lideranças indígenas, especialistas acadêmicos e agentes públicos que ele denomina de "ortodoxia aborígene". Essas proposições são: $i$ ) os povos tradicionais canadenses se distinguem da sociedade colonizadora por já ocuparem o território antes de sua 
chegada, o que lhes confere primazia temporal e o direito inerente à autonomia política; ii) as culturas indígenas e europeias estavam no mesmo nível tecnológico ao tempo da colonização e qualquer distinção que aponte a superioridade tecnológica desta última é uma forma de racismo opressor; iii) os povos indígenas eram e continuam a ser soberanos; $i v$ ) os povos indígenas eram "nações" no sentido cultural e político do termo; $v$ ) os povos indígenas podem exercer com sucesso seu direito à autonomia governamental no interior das reservas indígenas; vi) os direitos de propriedade dos povos indígenas devem ser considerados como direito pleno pela Constituição; vii) os tratados em algumas províncias devem ser "reinterpretados e renegociados" para dar uma formulação moderna ao seu conteúdo; e, por fim, viii) os povos indígenas, vivendo e trabalhando em seus próprios territórios, atingirão a prosperidade econômica por meio de uma combinação entre transferências governamentais, impostos provenientes da exploração de recursos naturais e emprego local.

Os capítulos do livro são dedicados a refutar cada um desses pontos e podem ser assim resumidos: i) povos indígenas eram em sua maioria nômades e não cobriam todo o território do país e, em certo sentido, os colonizadores europeus são os primeiros habitantes de muitas partes do país e, portanto, não são, tecnicamente, "invasores"; ii) a cultura e a tecnologia europeias estavam muitos milênios avançadas em relação à cultura dos autóctones da América do Norte e, dessa forma, "a colonização foi inevitável"; iii) a soberania é um atributo do estado moderno e, como tal, não pode ser aplicada a povos que desconheciam o conceito; iv) só há uma comunidade política soberana - o Canadá - e comunidades subalternas não são contempladas pelo conceito de nação; $v$ ) as comunidades indígenas são demasiado pequenas para poderem se autogerir e, no fim, são apenas pequenas organizações corruptas contaminadas por querelas familiais inúteis e destrutíveis; vi) o reconhecimento de um direito de propriedade territorial indígenas gera apenas incertezas jurídicas e não pode se viabilizar numa economia moderna; vii) a revisão de tratados não passa de revisionismo que reforça a 
incerteza jurídica e econômica em torno das terras indígenas; viii) a introdução de ajuda governamental financeira nas comunidades indígenas aumenta a dependência econômica desses grupos. Como se vê, tanto as proposições acerca da "ortodoxia aborígene" quanto suas "refutações" são, no mínimo, polêmicas, e merecem ser analisadas detidamente em artigos críticos.

Por fim, vale a pena mencionar, como obra de impacto no campo da política indigenista canadense, o trabalho dos cientistas políticos Frances Widdowson e Albert Howard, da Mount Royal University. Em sua obra conjunta Disrobing the aboriginal industry: the deception behind Indigenous cultural preservation (2008), os autores desenvolvem um approach similar ao de Tom Flanagam, ao criticarem, de forma veemente, o que chamam de "indústria aborígene", a qual entendem como a articulação de antropólogos, grupos indígenas, advogados, agentes públicos e ativistas em torno do tema das políticas para os povos indígenas canadenses. Esse conjunto de atores se beneficiaria, segundo os autores, de toda a economia relacionada ao assunto: antropólogos são contratados como consultores, povos indígenas ganham dinheiro por meio de transferências governamentais, advogados cobram caro para acompanhar os litígios nas cortes, e assim por diante. Para Widdowson e Howard, no entanto, todas essas atividades lucrativas baseiam-se em fraudes intelectuais e conceitos vagos, que não resistiriam a um escrutínio acadêmico mais rigoroso. A crítica à política de reconhecimento territorial indígena e políticas correlatadas seria interditada por um tabu, qual seja, a possibilidade de ser denunciada como um ato racista. Assim, argumentam os autores, perpetuam-se conceitos e práticas deletérias não apenas para o governo canadense, mas, sobretudo, para as populações indígenas, maldosamente "manipuladas" por uma elite intelectual e política que não se preocupa com a efetividade das políticas públicas, mas apenas com o lucro que estas podem gerar.

Concluímos esta seção afirmando que não apenas os temas trabalhados pelos cientistas políticos abordados na seção anterior são de interesse para o pesquisador interessado pelo tema no Brasil, 
mas também as críticas aqui explicitadas. Por um lado, estamos acostumados, em nosso meio acadêmico, com uma série de estudos normativos que endossam, com pouco olhar crítico, muitos aspectos problemáticos envolvidos nesse campo de estudos. Por outro, observamos com terror as críticas violentas, mal informadas e por vezes francamente racistas por parte de parlamentares e do senso comum da sociedade brasileira contra os povos indígenas. A articulação de uma crítica fundamentada e contundente aos pressupostos e visões de mundo que circulam no debate sobre a política indigenista e os povos indígenas brasileiros pode contribuir, de forma decisiva, para a o refinamento das políticas públicas voltadas para tão importante segmento populacional do país.

\section{Conclusões}

Neste artigo demonstramos, de forma empírica, a ausência prática de interesse do campo da ciência política brasileira sobre questões indígenas, refletida tanto no baixo número de trabalhos em nível de pós-graduação como na virtual ausência de artigos publicados nos principais periódicos do campo, além da absoluta ausência de atividades específicas dedicadas ao tema nos encontros da ABCP e do FBPGCP nos últimos oito anos. Na sequência, apresentamos um recorte do debate acadêmico canadense, apresentando três temas que julgamos de interesse para a ciência política brasileira. Por fim, abordamos, de forma ilustrativa, alguns dos principais críticos da indigenous politics naquele país. Ressalte-se que cada um dos livros abordados neste artigo merece, individualmente, um tratamento mais aprofundado, e conclamamos os cientistas políticos brasileiros a fazê-lo por meio de resenhas críticas e pesquisas utilizando-os à guisa de referencial teórico.

É importante frisar que a comunidade de pesquisadores em ciência política sobre temas relativos aos povos indígenas é pequena não apenas no Brasil, mas em todo o mundo. Wadsworth (2014), por exemplo, estima que apenas vinte cientistas políticos profissionais se dedicam contemporaneamente ao tema nos Estados Unidos da América. Christa Scholtz, por sua vez, afirmou-me que 
"é realmente difícil de compilar dados sobre assuntos indígenas, seja em arquivos, seja por meio de entrevistas. Essa é uma das razões pelas quais não há muitos cientistas políticos no campo". ${ }^{36}$ Assim, não é surpreendente que nossa comunidade de estudiosos sequer tenha se estabelecido, uma vez que ela é diminuta de modo geral em outros países.

É preciso denunciar o desinteresse dos cientistas políticos brasileiros sobre os temas relacionados aos povos tradicionais do país, sumariamente desconsiderados como objetos legítimos de reflexão científica em nosso campo disciplinar. Concluímos, portanto, lançando um apelo aos cientistas políticos brasileiros, tanto aqueles ainda em cursos de graduação quanto aqueles jovens doutores, para que desenvolvam trabalhos e pesquisas de maior fôlego sobre os povos indígenas e a política indigenista em nosso país. Motivos não faltam: o pleito de 2018 contou com o maior número de candidaturas indígenas em toda a história brasileira, incluindo a primeira candidata indígena à vice-presidência da República; ${ }^{37}$ a bancada ruralista dá sinais de que irá recrudescer sua atuação anti-indígena no Congresso Nacional, o que deverá dar ensejo a protestos do movimento indígena brasileiro; a PEC 215 ainda está em tramitação no Congresso, apenas esperando um momento para ser aprovada; e os desdobramentos da tese do marco temporal ${ }^{38}$ no Supremo Tribunal Federal ainda vão causar enorme repercussão política.

36 Comunicação pessoal em julho de 2017.

37 Trata-se da candidatura presidencial de Guilherme Boulos e Sônia Guajajara à presidência da República pelo Partido Socialismo e Liberdade (PSOL). A turbulência política que circunda as eleições de 2018 não deve obnubilar o fato histórico de que, pela primeira vez em 517 anos de invasão portuguesa à Pindorama e do estabelecimento do Estado brasileiro, uma mulher, negra, indígena e nordestina postulou o maior cargo da República. Atual coordenadora da Articulação dos Povos Indígenas do Brasil, Guajajara é uma liderança indígena respeitada em todo o país e, em conjunto com a eleição de Wapichaná, demonstra a vitalidade do Movimento Indígena brasileiro e, em especial, o papel central assumido pelas mulheres nesse contexto.

38 A chamada Tese do Marco Temporal diz respeito a uma interpretação constitucional, ainda não assentada e sujeita a controvérsias no âmbito do Supremo Tribunal Federal, que propugna a concepção de que o ano da promulgação da Constituição Federal de 1988 deve ser tomada como critério temporal para o julgamento da pertinência das demandas por reconhecimento de terras tradicionalmente ocupadas por povos indígenas no Brasil. Para uma ampla análise, do ponto de vista jurídico, sobre as implicações de tal entendimento para a materialização dos povos indígenas no país, ver Cunha e Barbosa (2018). 
Em suma, há muito material aguardando o interesse dos cientistas políticos brasileiros, e esperamos que este texto contribua para o desenvolvimento do campo entre nós.

\section{Referências}

ALCANTARA, Christopher. Negotiating the deal: comprehensive land claims agreements in Canada. Toronto: University of Toronto Press, 2013.

ALCANTARA, Christopher; NELLES, Jen. A quiet evolution: the emergence of Indigenous-local intergovernmental partnership in Canada. Toronto: University of Toronto Press, 2016.

ALFRED, Taiaiake. Heeding the voices of our ancestors: Kahnawake Mohawk politics and the rise of native nationalism. Oxford: Oxford University Press, 1995.

ALFRED, Taiaiake Peace, power and righteousness: an indigenous manifesto. Oxford: Oxford University Press, 2009.

ALFRED, Taiaiake Wasáse: Indigenous pathways of action and freedom. Peterborough: Broadview Press, 2005.

ALMEIDA, Alfredo Wagner Berno de. Terras de quilombo, terras indígenas, "babaçuais livres", “castanhais do povo", faxinais e fundos de pasto: terras tradicionalmente ocupadas. Manaus: PNCSA/UFAM, 2006. (Coleção Tradição e Ordenamento Jurídico, v. 2).

ANAYA, James. The situation of Indigenous peoples in Canada. Report of the Special Rapporteur on the rights of Indigenous peoples. New York: United Nations, 2014. Disponível em: https:// www.ohchr.org/documents/issues/ipeoples/sr/a.hrc.27.52.add.2missioncanada_auv.pdf. Acesso em: 20 jun. 2020.

ASCH, Michael. On being here to stay: treaties and aboriginal rights in Canada. Toronto: University of Toronto Press, 2014.

AVRITZER, Leonardo; MILANI, Carlos R.S; BRAGA, Maria do Socorro (org.). A ciência política no Brasil:1960-2015. Rio de Janeiro: FGV, 2016. 
BELANGER, Yale, D; LACKENBAUER, P. Whitney (ed.). Blockades or breakthroughs? Aboriginal peoples confront the Canadian state. Montreal: McGill-Queen's University Press, 2014.

BELLIER, Irène. Peuples autochtones dans le monde: les enjeux de la reconnaissance. Paris : L'Harmattan, 2013.

BRASIL. Censo demográfico de 2010. Brasília: IBGE, 2010. Disponível em: https://censo2010.ibge.gov.br/. Acesso em: 20 jun.2020.

CANADA. Aboriginal Affairs and Northern Development Canada. A demographic and socio-economic portrait of Aboriginal populations in Canada. Ottawa: AANDC, 2009.

CANADA. Aboriginal Affairs and Northern Development Canada. A history of treaty-making in Canada. Ottawa: AANDC, 2010. Disponível em: https://www.aadnc aandc. gc.ca/DAM/DAM-INTER-HQ/STAGING/texte-text/ap_htmc_ treatliv_1314921040169_eng.pdf. Acesso em: 20 jun. 2020. CANADA. Ministre de l'Industrie. Les peoples autochtones au Canada: Premières Nations, Métis et Inuits. Ottawa: Ministre de l'Industrie, 2011.

CÉLÉRIER, Philippe Pataud. A revolta dos povos autóctones do Canadá. Le Monde Diplomatique, Ano 7, n. 83, p. 26-27, 2014. COATES, Ken. Aboriginal land claims in Canada: a regional perspective. Copp Clark Pittman Ltda, 1992.

COATES, Ken. \#IdleNoMore: and the remaking of Canada. Regina:University of Regina Press, 2015.

CODATO, Adriano; LOBATO, Tiemi; CASTRO, André Oliveira. "Vamos lutar parentes!" As candidaturas indígenas nas eleições de 2014 no Brasil”. Revista Brasileira de Ciências Sociais, v. 32, n. 93, 2017.

COULTHARD, Glen Sean. Red skin, white masks: rejecting the colonial politics of recognition. Minneapolis: University of Minnesota Press, 2014.

CUNHA, Manuela Carneiro da; BARBOSA, Samuel (org.). Direitos dos povos indígenas em disputa. São Paulo: Editora Unesp, 2018. 
FERNANDES, Estevão Rodrigues. Ativismo homossexual indígena: uma análise comparativa entre Brasil e América do Norte. Dados, v. 58, n. 1, p. 257-294, jan./mar. 2015. Disponível em: https:// www.scielo.br/pdf/dados/v58n1/0011-5258-dados-58-1-0257.pdf. Acesso em: 20 jun. 2020.

FLANAGAN, Tom. First Nations? Second thoughts. Montreal: McGill-Queen's University Press, 2000.

FREIRE, Carlos Augusto da Rocha (org.). Memória do SPI: textos, imagens e documentos sobre o Serviço de Proteção aos Índios (1910-1967). Rio de Janeiro: Museu do Índio/Funai, 2011.

FRIEDERES, James S. First Nations people in Canada. Oxford: Oxford University Press, 2016.

GAGNON, Alain-G; IACOVINO, Raffaelle. Canadian federalism and multinational democracy: 'pressures' from Quebec on the federation. In: BAKVIS, Herman; SKOGSTAD, Grace (ed.) Canadian federalism: performance, effectiveness and legitimacy. Oxford: Oxford University Press, 2007.

LECLAIR, Jean. Instituitions autochtones et traditions juridiques: le cas canadien. In: BELLIER, Irene. Peuples autochtones dans le monde: les enjeux de la reconnaissance. Paris: L'Harmattan, 2013.

LEITE, Fernando. Tradições intelectuais na ciência política brasileira contemporânea. Dados, Rio de Janeiro, v. 60, n. 3, p.751-779, 2017. MISIARZ, Radoslaw. The Indian revolutionaries: the American Indian movement in the 1960s and 1970s. Bialostockie Tekie Historyczne, v. 15, 2017.

PALMATER, Pamela. Indigenous nationhood: empowering grassroots citizens. Nova Escócia: Fernwood Publishing, 2015.

PAPILLON, Martin. Aboriginal quality of life under a modern treaty: lessons from the experience of the Cree Nation of Eeyou Istchee and the Inuit of Nunavik. IRRP Choices, v. 14, n. 9, 2008.

PAPILLON, Martin. Canadian federalism and the emerging mosaic of Aboriginal multilevel governance. In: BAKVIS, Herman; SKOGSTAD, Grace (ed.). Canadian federalism: performance, effectiveness, and legitimacy. $3^{\text {rd }}$ ed. Oxford: Oxford University Press, 2012. 
PAPILLON, Martin. Framing self-determination: the politics of Indigenous rights in Canada and the United States. In: TURGEON, Luc et al. (Eds.). Comparing Canada: methods and perspectives on Canadian politics. Vancouver, BC: UBC Press, 2014.

PAPILLON, Martin. Vers un nouveau partenariat? Rapport sur la participation des communautés autochtones aux activités de mise en valeur des ressources naturelles hors Québec. [S.l.]: [S.n.], 2015. Disponível em: https://www.bibliotheque.assnat.qc.ca/ DepotNumerique_v2/AffichageNotice.aspx?idn=78852. Acesso em: 23 jun.2020.

PAPILLON, Martin; BEAULIEU, Alain; GERVAIS, Stéphan. Les autochtones et le Québec: des premiers contacts au plan nord. Montreal: Les Presses de l'Université de Montréal, 2013.

PAPILLON, Martin; LORD, Audrey. Les traités modernes: vers une nouvelle relation? In: PAPILLON, Martin; BEAULIEU, Alain; GERVAIS, Stéphan. Les autochtones et le Québec: des premiers contacts au Plan Nord. Montreal: Les Presses de l'Université de Montréal, 2013.

PAPILLON, Martin; SENÉCAL, Sasha . Traités modernes, qualité de vie et gouvernance des peoples autochtones au Canada: l'expérience de Cris et des Inuit sous la Convention de la Baie-James et du Nord Québécois. In: PETIT, Jacques-Guy et al. Les Inuit et les cris du Nord du Québec: territoire, gouvernance, societé et culture. Québec: Presses de l'Université du Québec, 2011.

PAULA, Luís Roberto de. A participação indígena em eleições municipais (1976 a 2016): uma sistematização quantitativa preliminar e alguns problemas de investigação. Resenha \& Debate, v. 2, 2017.

POELZER, Greg; COATES, Ken S. From treaty peoples to treaty nation: a road map for all Canadians. Vancouver: University of British Columbia Press, 2015.

RAMOS, Alcida Rita. Nações dentro da nação: um desencontro de ideologias. Brasília: DAN/UnB, 1993. (Série Antropologia, n. 147). Disponível em: http://www.dan.unb.br/images/doc/Serie147empdf. pdf. Acesso em: 23 jun. 2020. 
RAMOS, Howard. Opportunity for whom?: political opportunity and critical events in Canadian Aboriginal mobilization, 19512000. Social Forces, v. 87, n. 2, p. 795-823, 2008.

RRI - RIGHTS AND RESOURCES INITIATIVE. Who owns the world's land? A global baseline of formally recognized indigenous \& community land rights. Washington, DC: RRI, 2015. Disponível em: http://www.rightsandresources.org/wp-content/uploads/ GlobalBaseline_web.pdf. Acesso em: 2 mar. 2019.

SALÉE, Daniel. Quality of life of Aboriginal people in Canada: an analysis of current research; with the assistance of David Newhouse and Carol Lévesque. IRPP Choices, v.6, n. 12, 2006.

SCHOLTZ, Christa. Negotiating claims: the emergence of Indigenous land claim negotiation policies in Australia, Canada, New Zealand and the United States. Londres: Routledge, 2006.

SILVA, Christian Teófilo. Regimes de indianidade, tutela coercitiva e estadania: examinando a violência institucional contra indígenas no Brasil e no Canadá. Espaço Ameríndio, v. 10, n. 2, p. 194-222, 2016.

SOARES, Leonardo Barros. Idle No More: sobre a mobilização indígena no Canadá. Revista Brasileira de Ciências Sociais, v. 33, n. 97, 2018.

SOARES, Leonardo Barros. (Un)changing Indigenous land claims policy: evidences from a crossnational comparison between Brazil and Canada. Tese (Doutorado em Ciência Política) - Universidade Federal de Minas Gerais, Belo Horizonte, 2019.

SOARES, Leonardo Barros. Christopher Alcantara: reconhecendo demandas territoriais indígenas na América do Norte. Revista Brasileira de Ciência Política, n. 24, p 265-274, 2017 a.

SOARES, Leonardo Barros. Ciclos de protesto e repertório de ação do movimento indígena brasileiro entre 2009 e 2016:0 caso da PEC 215. Revista Brasileira de Ciência Política, n. 24, p 191-222, 2017 b. 
VAN COTT, Donna Lee. Radical democracy in the Andes: Indigenous parties and the quality of democracy in Latin America. Kellog Institute. Notre Dame, IN: Kellogg Institute, 2006. (Working Paper, n. 333). Disponível em: https://kellogg.nd.edu/sites/default/ files/old_files/documents/333_0.pdf. Acesso em: 23 jun. 2020. YASHAR, Deborah J. Contesting citizenship in Latin America: the rise of indigenous movements and the postliberal challenge. Cambridge: Cambridge University Press, 2005.

WADSWORTH, Nancy D. Unsettling lessons: teaching Indigenous politics and settler colonialism in political science. PS: Political Science \& Politics, v. 47, n. 3, p. 692-697, 2014.

WIDDOWSON, Frances; HOWARD, Albert. Disrobing the Aboriginal industry: the deception behind Indigenous cultural preservation. Montreal: McGill-Queen's University Press, 2008.

\section{Resumo:}

A análise empírica do Catálogo de Teses e Dissertações da Capes e de sete dos periódicos de grande circulação do campo da ciência política brasileira nos últimos vinte anos revela um grande desinteresse desse campo disciplinar em empreender pesquisas relacionadas às questões indígenas no Brasil. Este artigo apresenta, a partir da revisão bibliométrica e bibliográfica de 2.621 artigos e 47 teses e dissertações, os dados relativos ao caso brasileiro e um resumo do debate acadêmico sobre ciência política e povos indígenas no Canadá. Na sequência, apresentamos alguns trabalhos críticos da política indigenista e dos estudos sobre esse tema daquele país. Concluímos este artigo com um apelo à comunidade de cientistas políticos, estudantes e acadêmicos já estabelecidos, para o estabelecimento de uma agenda de pesquisa sobre este importante segmento social brasileiro.

Palavras-chave: Ciência política, Brasil, Povos indígenas, Canadá.

\section{Abstract:}

An empirical analysis of the Catálogo de Teses e Dissertações of the CAPES and of seven important Brazilian political science journals over the last twenty years shows a significative lack of interest in researching Indigenous issues. This paper uses bibliometric analysis and carries out 
an extensive literature review of 2,621 papers and 47 Master's theses and doctoral dissertations to prove this claim and to present to Brazilian readers political science research on Indigenous peoples in Canada, highlighting topics of interest. We then present some critical views of Indigenous policy and studies on this topic in that country. We conclude by calling for the Brazilian political science community, both scholars and students, to establish a research agenda on this important segment of the country's population.

Keywords: Political Science, Brazil, Indigenous peoples, Canada.

Recebido em 10 de março de 2019

Aprovado em 20 de junho de 2020 